\title{
Manajemen Anestesi pada Seksio Sesarea dengan Idiopathic Thrombocytopenic Purpura: Serial kasus
}

\author{
Achmad Hariyanto', Ruddi Hartono ${ }^{2}$, Isngadi ${ }^{2}$ \\ ${ }^{1}$ Residen Anestesiologi \& Terapi Intensif, Fakultas Kedokteran, Universitas Brawijaya, RSUD Dr. Saiful Anwar, \\ Malang, ${ }^{2}$ Spesialis Anestesi, Fakultas Kedokteran, Universitas Brawijaya, RSUD Dr. Saiful Anwar, Malang
}

\begin{abstract}
Abstrak
Trombositopenia merupakan perubahan hemostasis yang umum terjadi pada wanita hamil, namun jarang ditemukan kondisi berat. Idiopathic thrombocytopenic purpura (ITP) merupakan salah satu penyebab trombositopenia pada wanita hamil. ITP ditandai dengan peningkatan penghancuran trombosit oleh antibodi immunoglobulin $\mathrm{G}$ (IgG) yang dapat meningkatkan risiko perdarahan pada pasien dan fetus. Kami melaporkan tiga kasus wanita hamil dengan ITP yang akan dilakukan tindakan seksio sesarea. Satu pasien menjalani seksio sesarea emergency dengan trombosit 4000 dan dua pasien menjalani seksio sesarea elektif. Pasien seksio sesarea elektif diberikan transfusi trombosit perioperatif terlebih dahulu. Ketiga pasien menjalani prosedur seksio sesarea dengan teknik anestesi general. Pemantauan perdarahan dilakukan selama sampai dengan setelah operasi. Kondisi postoperatif pasien baik dan dirawat di ruang intensive care unit (ICU).
\end{abstract}

Kata kunci: Idiopathic thrombocytopenic purpura, ITP, kehamilan, seksio sesarea

\section{Case Series: Anesthesia Management in Caesarean Section with Idiopathic Thrombocytopenic Purpura}

\begin{abstract}
Thrombocytopenia is the most common hemostatic change in pregnancy, but severe thrombocytopenia is rare. One of the causes, idiopathic thrombocytopenic purpura (ITP), is characterized by increased platelet destruction by immunoglobulin $\mathrm{G}(\mathrm{IgG})$ antibodies, presenting a high risk of hemorrhage for the patient, but also the fetus, since antibodies may cross the placenta. We report three cases of pregnant women with ITP undergoing cesarean section. One patient underwent emergency cesarean section with a platelet of 4000 and two patients underwent elective cesarean. Patients with elective cesarean section were given the first perioperative platelet transfusion. The cesarean section procedures were performed under general anesthesia. Bleeding monitoring is carried out during up to after surgery. The patient's postoperative condition was good and was treated in the intensive care unit.
\end{abstract}

Key words: Idiopathic thrombocytopenic purpura, pregnancy caesarean section 


\section{Pendahuluan}

Trombositopenia didefinisikan sebagai nilai trombosit $<150.000 \mathrm{mcL}$ dan merupakan kelainan hematologi yang umum dijumpai pada wanita hamil. Trombositopenia yang terjadi secara fisiologis pada wanita hamil disebabkan karena adanya ekspansi plasma, hemodilusi, dan peningkatan aktivasi platelet, dan biasanya berlangsung ringan tanpa gejala. Trombositopenia pada wanita hamil disebabkan oleh beberapa etiologi, yaitu infeksi, defisiensi asam folat, kelainan hematologi, destruksi imunologis, dan perdarahan. ${ }^{1}$ Data epidemiologi menunjukkan trombositopenia terjadi pada $7,7 \%$ wanita hamil, dimana $78,3 \%$ disebabkan oleh trombositopenia gestasional, penyebab trombosito-penia yang lain yaitu komplikasi hipertensi atau preeklampsia sebesar 15,\%, dan disebabkan oleh idiopathic thrombocytopenic purpura (ITP) sebesar 1,6\%. ITP adalah kelainan autoimun dimana terjadi destruksi sel trombosit oleh sistem retikuloendotelial yang menyebabkan penurunan jumlah trombosit pada aliran darah perifer. ${ }^{2}$ Wanita hamil yang memiliki angka trombosit $<50.000 / \mu \mathrm{L}$ memiliki risiko terjadi perdarahan pada periode peripartum sehingga dibutuhkan pemantauan dan manajemen anestesi yang hati-hati pada pasien tersebut.3 Kami menyajikan laporan manajemen anestesi pada tiga kasus ibu hamil yang menderita ITP dan akan menjalani prosedur seksio sesarea. Satu orang pasien menjalani prosedur seksio sesarea emergency dengan trombosit 4000, dan dua pasien menjalani seksio sesarea elektif dengan trombosit $>50.000$.

\section{Kasus}

Kasus 1

Anamnesis

Seorang wanita, 23 tahun dengan berat badan $58 \mathrm{~kg}$, diagnosis G1P000Ab000 37-38 minggu, janin tunggal, hidup, dengan idiophatic thrombocytopenic purpura (ITP) direncanakan seksio sesarea. Pasien diketahui terdiagnosis ITP sejak 10 tahun yang lalu dan dalam pengobatan metilprednisolon oral. Pasien memiliki riwayat alergi ceftriaxone. Pasien rencana dikerjakan di IGD karena sudah ada pembukaan.
Pemeriksaan Fisik

Pada pemeriksaan fisik didapatkan pasien dalam keadaan sadar GCS E4V5M6 dengan tekanan darah 127/77mmHg, denyut jantung 106 bpm, kuat angkat, laju respirasi $22 \mathrm{x} / \mathrm{i}$. pemeriksaan jantung paru dalam batas normal. Konjungtiva tidak tampak anemis, akral hangat dan CRT < 2 detik. Denyut jantung janin 138 bpm. Tampak ptekie di dada dan lengan kanan atas.

\section{Pemeriksaan Penunjang}

Pasien telah dirawat di rumah sakit selama 7 hari dan mendapatkan transfusi trombosit bertahap sebanyak 24 kolf. Trombosit awal pasien 4000, naik menjadi 7000 setelah transfusi, namun kembali turun menjadi 4000.

Tabel. 1 Hasil Pemeriksaan Laboratorium Pre Operatif Pasien 1

\begin{tabular}{lll}
\hline Pemeriksaan & Hasil & Satuan \\
\hline Hemoglobin & 9,7 & $\mathrm{~g} / \mathrm{dl}$ \\
Hematokrit & 33 & $\%$ \\
Leukosit & 14,840 & $/ \mathrm{mcl}$ \\
Trombosit & 4.000 & $/ \mathrm{mcl}$ \\
PT & 10,1 & detik \\
APTT & 21 & detik \\
INR & 0,95 & \\
Albumin & 3,5 & $\mathrm{~g} / \mathrm{dl}$ \\
Ureum & 29,8 & $\mathrm{mg} / \mathrm{dl}$ \\
Kreatinin & 0,5 & $\mathrm{mg} / \mathrm{dl}$ \\
Natrium & 132 & $\mathrm{mmol} / 1$ \\
Kalium & 3,2 & $\mathrm{mmol} / \mathrm{l}$ \\
Clorida & 105 & $\mathrm{mmol} / \mathrm{l}$ \\
\hline
\end{tabular}

Pengelolaan Anestesi

Pasien dilakukan seksio sesarea emergency dengan ASA 3. Sebelum operasi, pasien sudah mendapatkan terapi metiplrednisolon oral $2 \times 125 \mathrm{mg}$ selama 14 hari, dan pemberian immunoglobulin intravena. Keluarga di inform consent prosedur pembiusan dan resiko yang mungkin terjadi selama operasi. Akses intravena dipasang dua jalur dengan $i v$ cath no. 18. Pasien dipuasakan, dan diberikan metoclopramide 10 $\mathrm{mg}$ iv dan ranitidin $50 \mathrm{mg}$ iv sebagai profilaksis pneumonitis aspirasi. Pasien dilakukan teknik anestesia general dan intubasi. Selama operasi 


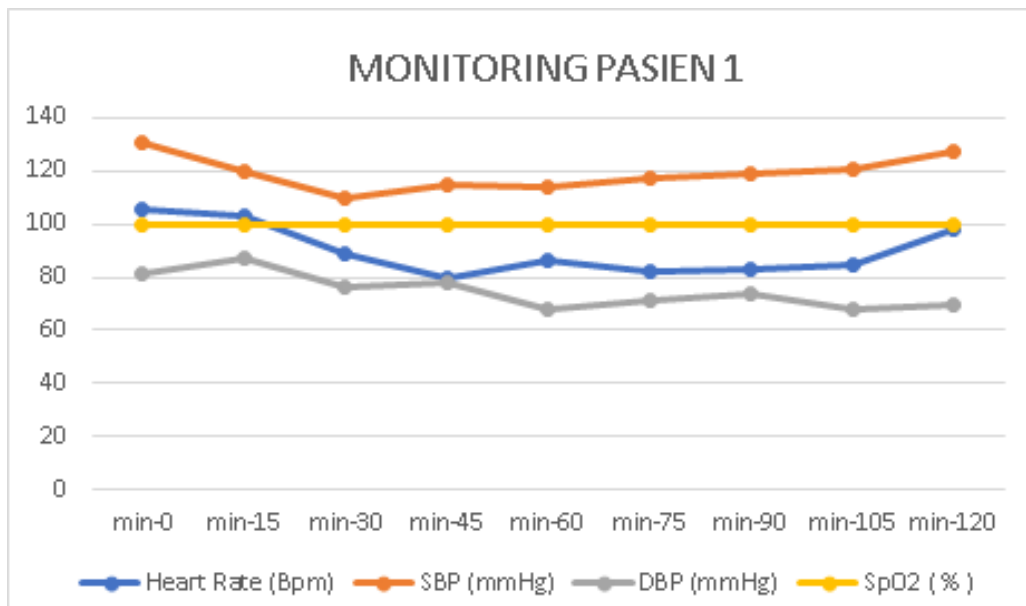

Grafik 1. Hemodinamik Saat Durante Operasi Pasien 1

berlangsung, darah yang keluar sebanyak 500 cc, dan pasien mendapatkan transfusi trombosit sebanyak 1146cc, fresh frozen plasma (FFP) sebanyak $500 \mathrm{cc}$, dan packed red cell (PRC) sebanyak $510 \mathrm{cc}$. Pasca operasi, pasien dirawat di ICU dengan nafas spontan

\section{Pengelolaan Pascabedah}

Hari pertama perawatan post operasi, didapatkan kondisi pasien composmentis, tekanan darah $127 / 77 \mathrm{mmHg}$, frekuensi nadi $106 \mathrm{kali} /$ menit regular, frekuensi napas $20 \mathrm{kali} / \mathrm{menit}$. Ditemukan ptekie $(+)$. Tidak didapatkan perembesan darah dari tempat jahitan. Hasil laboratorium trombosit 6.000, kalium 2,83 dan asam laktat 4,1. Pasien diberikan terapi injeksi cefazolin $2 \times 1$ gram intravena, injeksi metilprednisolon 2x125 mg intravena, injeksi ranitidin 2x50 mg intravena, syringe pump asam tranexamat $1 \mathrm{mg} / \mathrm{kg} / \mathrm{jam}$, fentanyl $20 \mathrm{mcg} / \mathrm{jam}$, dan $\mathrm{KCl} 100 \mathrm{meq} / 24 \mathrm{jam}$, drip oxitosin $20 \mathrm{IU}+\mathrm{RL} 500 \mathrm{cc} 28 \mathrm{tpm}$ dalam 24 jam post operasi, eltrombopag $2 \times 50 \mathrm{mg}$ per oral, dan transfusi trombosit 6 kolf. Hari kedua perawatan post operasi, didapatkan kondisi pasien compos mentis, tekanan darah 130/89 $\mathrm{mmHg}$, nadi $85 \mathrm{kali} / \mathrm{menit}$ regular, frekuensi

Tabel. 2 Hasil Pemeriksaan Laboratorium Pasca Operatif Pasien 1 di ICU

\begin{tabular}{lllll}
\hline Pemeriksaaan & Hasil & Hasil & Hasil & Satuan \\
& Hari ke 1 & Hari ke 2 & Hari ke & \\
\hline Hemoglobin & 9 & 10,3 & 9,4 & $\mathrm{~g} / \mathrm{dl}$ \\
Hematokrit & 27,9 & 30 & 29,4 & $\%$ \\
Leukosit & 29,420 & 40.000 & 47.000 & $/ \mathrm{mcl}$ \\
Trombosit & 6.000 & 3.000 & 4.000 & $/ \mathrm{mcl}$ \\
PT & 10,1 & & & detik \\
APTT & 21,9 & & & detik \\
INR & 0,97 & & & \\
Albumin & 3,8 & & & $\mathrm{~g} / \mathrm{dl}$ \\
Ureum & 29,8 & & $\mathrm{mg} / \mathrm{dl}$ \\
Kreatinin & 0,5 & & $\mathrm{mg} / \mathrm{dl}$ \\
Natrium & 132 & 133 & $\mathrm{mmol} / \mathrm{l}$ \\
Kalium & 2.83 & 4,01 & $\mathrm{mmol} / \mathrm{l}$ \\
Clorida & 105 & 107 & $\mathrm{mmol} / \mathrm{l}$ \\
Laktat & 4,1 & & & \\
\hline
\end{tabular}


napas $18 \mathrm{kali} /$ menit. Ditemukan ptekie $(+)$. Tidak ada perembesan darah dari tempat jahitan. Hasil laboratorium trombosit 3.000 dan kalium 4,01. Pasien diberikan terapi injeksi cefazolin $2 \times 1$ gram intravena, injeksi metilprednisolon $2 \times 125$ $\mathrm{mg}$ intravena, injeksi ranitidin $2 \times 50 \mathrm{mg}$ intravena, injeksi methergine $3 \times 1$ intravena, syringe pump asam tranexamat $1 \mathrm{mg} / \mathrm{kg} / \mathrm{jam}$, fentanyl $20 \mathrm{mcg} /$ jam, eltrombopag $2 \times 50 \mathrm{mg}$ per oral. Hari ketiga perawatan post operasi, didapatkan kondisi pasien composmentis, tekanan darah 127/80 $\mathrm{mmHg}$, nadi $82 \mathrm{kali} / \mathrm{menit}$ reguler, frekuensi napas $18 \mathrm{kali} / \mathrm{menit}$. Ditemukan ptekie $(+)$. Tidak ada perembesan darah dari tempat jahitan. Hasil laboratorium trombosit 4.000. Pasien diberikan terapi injeksi metronidazole $3 \times 500 \mathrm{mg}$ intravena, injeksi gentamisin $2 \times 80 \mathrm{mg}$ intravena, injeksi metilprednisolon 2x125 mg intravena, injeksi ranitidin $2 \times 50 \mathrm{mg}$ intravena, injeksi methergine $3 \mathrm{x} 1$ intravena, syringe pump asam tranexamat $1 \mathrm{mg} / \mathrm{kg} / \mathrm{jam}$, eltrombopag $2 \times 50 \mathrm{mg}$ per oral, dan transfusi trombosit. Pasien dipindah ke ruangan biasa karena observasi selama 3 hari hemodinamik stabil.

\section{Kasus 2}

Anamnesis

Seorang wanita, 31 tahun dengan berat badan $59 \mathrm{~kg}$, tinggi badan $156 \mathrm{~cm}(\mathrm{BMI}=24,2)$, diagnosis G4P1001Ab200gr 38-39 minggu, janin tunggal, hidup, dengan ITP akan dilakukan seksio sesarea. Pasien diketahui terdiagnosis ITP sejak 2 tahun yang lalu dan dalam pengobatan metilprednisolon oral $2 \times 62,5 \mathrm{mg}$.

\section{Pemeriksaan Fisik}

Pada pemeriksaan fisik didapatkan pasien dalam keadaan sadar GCS E4V5M6 dengan tekanan darah 110/81 $\mathrm{mmHg}$, denyut jantung $73 \mathrm{bpm}$, kuat angkat, laju respirasi $18 \mathrm{x} / \mathrm{m}$. pemeriksaan jantung paru dalam batas normal. Konjungtiva tidak tampak anemis, akral hangat dan CRT $<2$ detik, tidak didapatkan tanda perdarahan maupun ptekie. Denyut jantung janin 148 bpm.

\section{Pemeriksaan Penunjang}

Pasien dirawat di rumah sakit dengan trombosit 15.000, dilakukan tranfusi $600 \mathrm{cc}$ TC sebanyak

2 kali. Nilai trombosit naik menjadi 28.000 kemudian 67,000.

Pengelolaan Anestesi

Pasien dilakukan seksio sesarea elektif dengan ASA 3, Pasien dilakukan anestesia

Tabel. 3 Hasil Pemeriksaan laboratorium Pre Operatif Pasien 2

\begin{tabular}{lll}
\hline Pemeriksaan & Hasil & Satuan \\
\hline Hemoglobin & 9,3 & $\mathrm{~g} / \mathrm{dl}$ \\
Hematokrit & 28,9 & $\%$ \\
Leukosit & 9.830 & $/ \mathrm{mcl}$ \\
Trombosit & 67,000 & $/ \mathrm{mcl}$ \\
PT & 9,9 & detik \\
APTT & 23,9 & detik \\
INR & 0,95 & \\
Albumin & 3,98 & $\mathrm{~g} / \mathrm{dl}$ \\
Ureum & 19 & $\mathrm{mg} / \mathrm{dl}$ \\
Kreatinin & 0,56 & $\mathrm{mg} / \mathrm{dl}$ \\
Natrium & 132 & $\mathrm{mmol} / 1$ \\
Kalium & 3,16 & $\mathrm{mmol} / \mathrm{l}$ \\
Clorida & 110 & $\mathrm{mmol} / \mathrm{l}$ \\
\hline
\end{tabular}

general dan intubasi. Selama operasi, darah yang keluar sebanyak $500 \mathrm{cc}$, dan pasien mendapatkan transfusi trombosit sebanyak $500 \mathrm{cc}$, dan PRC sebanyak 250 cc. Pasien hemodinamik stabil selama durante, post operasi dilakukan ekstubasi dan monitoring di ICU

\section{Pengelolaan Pascabedah}

Hari pertama perawatan post operasi di ICU, didapatkan kondisi pasien compos mentis, tekanan darah 122/82 $\mathrm{mmHg}$, nadi $82 \mathrm{kali} /$ menit regular, frekuensi napas $16 \mathrm{kali} /$ menit. Tidak ada perembesan darah dari tempat jahitan dan tidak ada tanda ptekie. Hasil laboratorium trombosit 93,000. Pasien diberikan terapi injeksi cefazolin $2 \times 1$ gram intravena, injeksi metilprednisolon 2x125 mg intravena, injeksi ranitidin $2 \times 50 \mathrm{mg}$ intravena, injeksi methergine $3 \times 1$ intravena, fentanyl 20 $\mathrm{mcg} / \mathrm{jam}$. Pasien dipindah ke ruangan biasa.

\section{Kasus 3}

Anamnesis

Seorang wanita, 34 tahun, berat badan $60 \mathrm{~kg}$, 


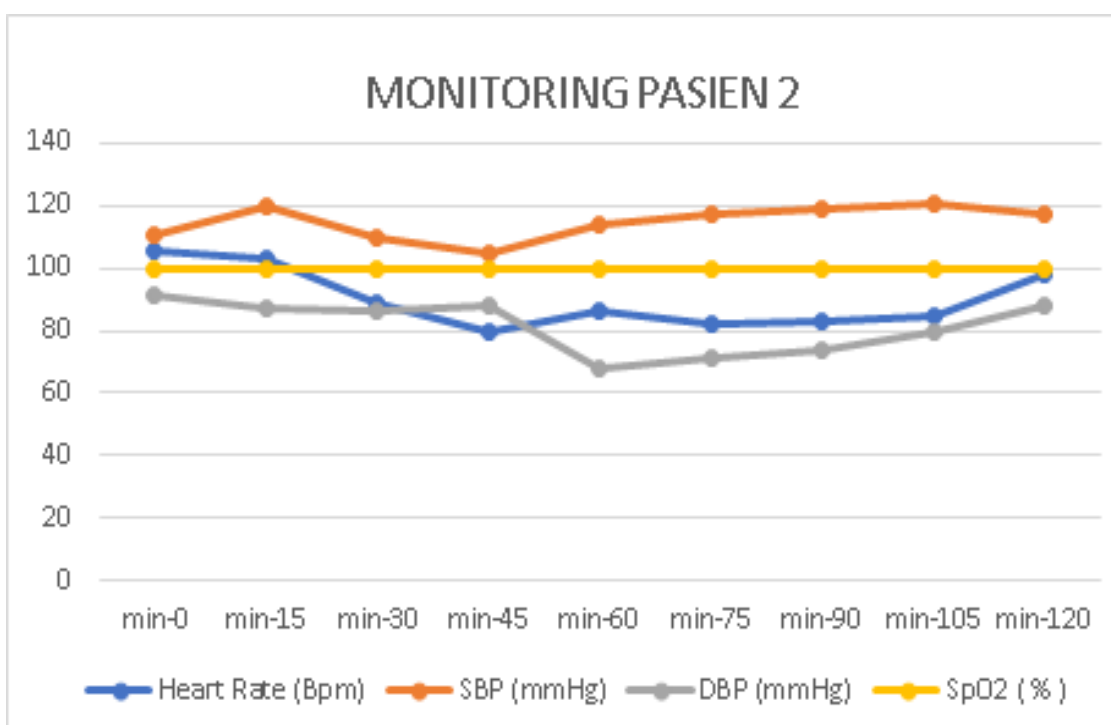

Grafik 2. Hemodinamik saat Durante Operasi Pasien 2

Tabel. 4 Hasil Pemeriksaan Laboratorium Pasca Operatif Pasien 2

\begin{tabular}{lll}
\hline Pemeriksaan & Hasil & Satuan \\
\hline Hemoglobin & 10,5 & $\mathrm{~g} / \mathrm{dl}$ \\
Hematokrit & 32,2 & $\%$ \\
Leukosit & 12.970 & $/ \mathrm{mcl}$ \\
Trombosit & 93.000 & $/ \mathrm{mcl}$ \\
PT & 9,6 & detik \\
APTT & 25 & detik \\
INR & 0,95 & \\
Albumin & 3,98 & $\mathrm{~g} / \mathrm{dl}$ \\
\hline
\end{tabular}

tinggi badan $156 \mathrm{~cm}(\mathrm{BMI}=24,6)$, diagnosis G4P1101Ab100 gr 37 - 38 minggu, janin tunggal, hidup, dengan ITP. Pasien diketahui terdiagnosis ITP dan dalam pengobatan metilprednisolon oral $2 \times 62,5 \mathrm{mg}$ sejak 3 tahun yang lalu.

\section{Pemeriksaan Fisik}

Pada pemeriksaan fisik didapatkan pasien dalam keadaan sadar GCS E4V5M6 dengan tekanan darah $104 / 67 \mathrm{mmHg}$, denyut jantung $83 \mathrm{bpm}$, kuat angkat, laju respirasi $18 \mathrm{x} / \mathrm{m}$. pemeriksaan jantung paru dalam batas normal. Konjungtiva tidak tampak anemis, akral hangat dan CRT $<2$ detik, tidak didapatkan tanda perdarahan maupun ptekie. Denyut jantung janin 148 bpm.
Pemeriksaan Penunjang

Hasil laboratorium awal saat pasien masuk yaitu trombosit 3.000. Pasien telah mendapatkan transfusi trombosit bertahap selama 8 hari dan trombosit naik bertahap menjadi 9.000; 24.000; $38.000 ; 74.000$.

Pengelolaan Anestesi

Pasien akan dilakukan seksio sesarea elektif dengan ASA 3. Disiapkam 2PRC dan $500 \mathrm{cc}$ TC.

Tabel. 5 Hasil Pemeriksaan laboratorium Pre Operatif Pasien 3

\begin{tabular}{lll}
\hline Pemeriksaan & Hasil & Satuan \\
\hline Hemoglobin & 10,8 & $\mathrm{~g} / \mathrm{dl}$ \\
Hematokrit & 33,1 & $\%$ \\
Leukosit & 15.360 & $/ \mathrm{mcl}$ \\
Trombosit & 74.000 & $/ \mathrm{mcl}$ \\
PT & 9.8 & detik \\
APTT & 27.1 & detik \\
INR & 0.94 & \\
Ureum & 17 & $\mathrm{mg} / \mathrm{dl}$ \\
Kreatinin & 0.59 & $\mathrm{mg} / \mathrm{dl}$ \\
Natrium & 135 & $\mathrm{mmol} / 1$ \\
Kalium & 4.2 & $\mathrm{mmol} / \mathrm{l}$ \\
Clorida & 109 & $\mathrm{mmol} / 1$ \\
\hline
\end{tabular}


Sebelum dilakukan induksi dipasang iv line 2 jalur nomer 18 G. Pasien dilakukan anestesi general dan intubasi. Selama operasi, darah yang keluar sebanyak 200 cc. Pasien tidak mendapatkan transfusi selama operasi karena kondisi hemodinamik stabil dan perdarahan terkontrol.

\section{Pengelolaan Pascabedah}

Hari pertama perawatan post operasi di ICU, didapatkan kondisi pasien compos mentis, tekanan darah 107/70 $\mathrm{mmHg}$, nadi $76 \mathrm{kali} / \mathrm{menit}$ reguler, frekuensi napas $18 \mathrm{kali} / \mathrm{menit}$. Tidak ada perembesan darah dari tempat jahitan. Hasil laboratorium trombosit 70.000. Pasien diberikan terapi injeksi injeksi metilprednisolon 2x125 mg intravena, injeksi ranitidin $2 \times 50 \mathrm{mg}$ intravena, injeksi methergine $3 \times 1$ intravena, syringe pump asam tranexamat $1 \mathrm{mg} / \mathrm{kg} / \mathrm{jam}$ dan syringe fentanyl 20mcg/jam. Hari pertama, pasien dipindah ke ruangan biasa.

Tabel 7. Perbandingan Nilai Trombosit Pre dan Pasca Operatif pada Ketiga Pasien

\begin{tabular}{llll}
\hline Pasien & $\begin{array}{c}\text { Trombosit Pre } \\
\text { operatif }\end{array}$ & $\begin{array}{c}\text { Trombosit } \\
\text { Pasca operatif }\end{array}$ & Satuan \\
\hline 1 & 4.000 & 6.000 & $/ \mathrm{mcl}$ \\
2 & 67,000 & 93.000 & $/ \mathrm{mcl}$ \\
3 & 74.000 & 70.000 & $/ \mathrm{mcl}$ \\
\hline
\end{tabular}

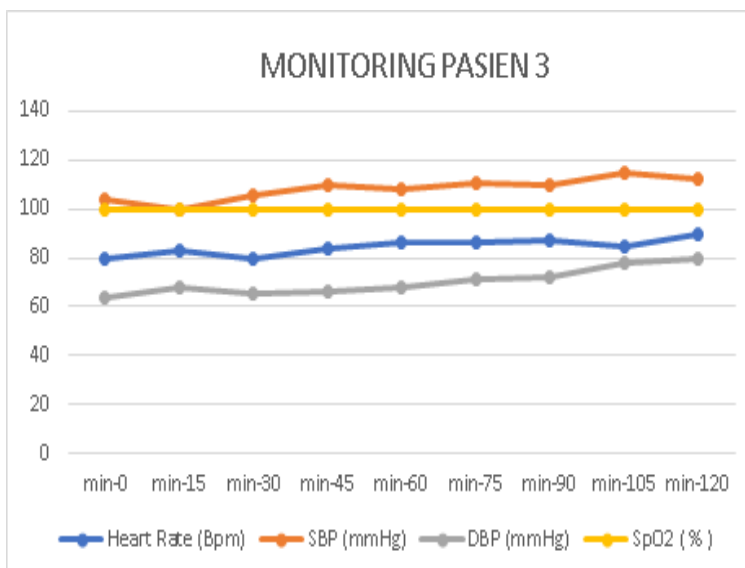

Grafik 3. Hemodinamik saat Durante Operasi Pasien 3

\section{Pembahasan}

Trombositopenia merupakan kelainan hematologi
Tabel. 6 Hasil Pemeriksaan Laboratorium Pasca Operatif Pasien 3

\begin{tabular}{lll}
\hline Pemeriksaan & Hasil & Satuan \\
\hline Hemoglobin & 9,0 & $\mathrm{~g} / \mathrm{dl}$ \\
Hematokrit & 30.1 & $\%$ \\
Leukosit & 14.20 & $/ \mathrm{mcl}$ \\
Trombosit & 70.000 & $\mathrm{c}$ \\
PT & 10,1 & detik \\
APTT & 26,4 & detik \\
INR & 0,97 & \\
Ureum & 27 & $\mathrm{mg} / \mathrm{dl}$ \\
Kreatinin & 0.6 & $\mathrm{mg} / \mathrm{dl}$ \\
Natrium & 136 & $\mathrm{mmol} / 1$ \\
Kalium & 4,0 & $\mathrm{mmol} / 1$ \\
Clorida & 110 & $\mathrm{mmol} / 1$ \\
\hline
\end{tabular}

yang umum dijumpai pada wanita hamil. Nilai trombosit normal berkisar antara 150.000

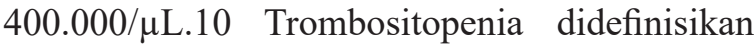
seba-gai nilai trombosit $<150.000 / \mu \mathrm{L}$. Trombositopenia yang terjadi secara fisiologis pada wanita hamil disebabkan karena adanya ekspansi plasma, hemodilusi, dan peningkatan aktivasi platelet, dan biasanya berlangsung ringan tanpa gejala. Trombositopenia pada wanita hamil disebabkan oleh beberapa etiologi, yaitu infeksi, defisiensi asam folat, kelainan hematologi, destruksi imunologis, dan perdarahan aktif dalam jumlah banyak. ${ }^{1}$

Angka insidensi wanita hamil dengan trombositopenia sebesar 1-2/1000 kasus dimana $5 \%$ kasus trombositopenia terkait kehamilan merupakan ITP, dan 15\% wanita hamil dengan ITP memiliki jumlah trombosit $<50.000 / \mu \mathrm{L}$ pada saat melahirkan. Trombositopenia gestasional dapat diamati pada 5,8\% wanita hamil. Trombositopenia gestasional hanya dapat didiagnosis dengan menyingkirkan penyebab trombositopenia yang lainnya. Trombositopenia gestasional dapat terjadi pada trimester kedua dan ketiga, perjalanan penyakit berlangsung ringan dan tidak berhubungan dengan rsiko perdarahan. Angka trombosit berkisar $<70.000 /$ $\mu \mathrm{L}$ dan dapat kembali normal dalam 12 minggu setelah melahirkan. Pasien tidak memiliki riwayat 
trombositopenia sebelum kehamilan, namun pada beberapa kasus dapat terdeteksi trombositopenia ringan pada riwayat kehamilan sebelumnya. ${ }^{4}$ Idiopathic thrombocytopenic purpura (ITP) ditandai dengan kondisi trombositopenia tanpa diketahui penyebabnya. Angka kejadian ITP pada populasi dewasa berkisar antara 1,6-6,6/100.000 orang per tahun. ${ }^{2}$ Sebuah penelitian menunjukkan trombositopenia terjadi pada $7,7 \%$ wanita hamil, dimana $78,3 \%$ disebabkan oleh trombositopenia gestasional, penyebab trombosito-penia yang lain yaitu komplikasi hipertensi atau preeklampsia sebesar $15 \%$, dan disebabkan oleh ITP sebesar $1,6 \% .^{5}$

Idiopathic thrombocytopenic purpura (ITP) merupakan penyakit autoimun yang berhubungan dengan produksi immunoglobulin IgGantiplatelet. Patogenesis terjadinya ITP yaitu terdapat autoantibodi terhadap glikoprotein membran trombosit, terutama GPIIb/IIIa dan GPIb/IX, dan terjadi penghancuran trombosit yang berlapis IgG tersebut oleh sistem retikuloendotelial, terutama pada spleen. ITP ditandai dengan kondisi trombositopenia persisten dengan atau tanpa adanya megakariosit pada darah perifer, dan kadar megakariosit normal atau meningkat pada aspirat sumsum tulang tanpa adanya splenomegali. Gejala klinis pada ITP yaitu terdapat ptekie dan memar pada tubuh, namun pada beberapa pasien dapat asimptomatis dan terdiagnosis berdasarkan hasil laboratorium. ${ }^{6}$

Di luar kehamilan, pedoman nasional dan internasional merekomendasikan untuk pengobatan ITPketika trombositdi bawah 30x109/ L. ${ }^{13,14} \mathrm{Di}$ atas ambang batas ini direkomendasikan perawatan jika ada tanda perdarahan atau jika operasi dalam waktu dekat diperlukan. Ambang batas pengobatan ini telah diadaptasi pada kehamilan. ITP tidak membutuhkan pengobatan pada trimester pertama dan kedua kehamilan kecuali jumlah trombosit turun di bawah 30x109/L.15. ${ }^{15}$ Persalinan pervaginam umumnya dianggap aman pada jumlah trombosit di atas 20-30x109/L. Menjelang aterm, jumlah trombosit seharusnya di atas 50x109/L untuk memungkinkan persalinan caesar yang aman jika diperlukan. ${ }^{16}$ Trombositopenia pada kehamilan harus dievaluasi secara hati-hati sehubungan dengan tingkat keparahan trombositopenia, periode kehamilan saat diagnosis awal, dan penyebabnya. Secara khusus, pasien dengan ITP harus dievaluasi dengan hati-hati dan mungkin membutuhkan transfusi jika jumlah trombosit < $50.000 / \mu \mathrm{L} .{ }^{11}$

Terapi lini pertama untuk ITP yaitu pemberian kortikosteroid (prednisolon $1 \mathrm{mg} / \mathrm{kg}$ ) dan immunoglobulin intravena $1-2$ gram $/ \mathrm{kg}$ yang diberikan selama 1-5 hari. Terapi rumatan dapat diberikan kombinasi danazol $10-15 \mathrm{mg} / \mathrm{kg}$ dan azathioprine $2 \mathrm{mg} / \mathrm{kg}$ yang diberikan secara per oral. Pada pasien ITP yang tidak merespon dengan pemberian obat-obatan, maka pilihan terapi yaitu splenektomi. ${ }^{1}$ Pada wanita hamil dengan ITP dapat diberikan terapi steroid dengan dosis $1 \mathrm{mg} / \mathrm{kg} / \mathrm{hari}$, dosis efektif minimal dapat diturunkan sexara bertahap setelah 2-3 minggu atau diberikan intravena immunoglobulin dengan dosis $0,4 \mathrm{gram} / \mathrm{kg} /$ hari selama 5 hari. Pemberian immunoglobulin intravena dapat diberikan sampai dengan setelah melahirkan. Kombinasi IVIg dan kortikosteroid efektif pada pasien yang refrakter, meskipun telah dikaitkan dengan peningkatan risiko efek samping pada satu penelitian. ${ }^{17}$ Terapi lini kedua untuk ibu hamil yaitu azathioprine, anti-D dan cyclosporine, termasuk splenectomy dapat dilakukan pada trimester kedua. Rituximab dapat menembus plasenta dan dapat menyebabkan depresi sel B neonatus apabila diberikan pada lebih dari 6 bulan sebelum melahirkan. Pemberian vinca alkaloid, cyclophosphamide, danazol, dan thrombopoietin mimetic sebaiknya dihindari pada wanita hamil., ${ }^{2,7}$

Komplikasi yang dapat terjadi pada wanita hamil denganITPyaitu terjadinyaperdarahan.Pada fetus, komplikasi dapat terjadi apabila IgG antiplatelet maternal melewati plasenta dan mengakibatkan ITP pada fetus. Pada saat melahirkan, antara $10 \%$ $-20 \%$ fetus memiliki trombosit $<50 \times 109 / \mathrm{L}$ dan $5 \%$ fetus memiliki jumlah trombosit $<20 \times 109 / \mathrm{L}$. Selama intrapartum, komplikasi lain yang dapat terjadi pada fetus yaitu intracranial hemorrhage, meskipun angka kejadiannya sangat jarang, namun dapat mengakibatkan kelainan neurologis bahkan kematian. Pemantauan kadar trombosit pada neonatus baru lahir sebaiknya dilakukan 
secara serial, dikarenakan kadar trombosit neonatus dapat berkurang dalam waktu $4-5$ hari postpartum dan kembali normal dalam waktu 1 bulan. ${ }^{6,8,9,18}$

Berdasarkan guidelines of British Committee for Standards in Haematology, pada pasien dengan trombosit $>80.000 / \mu \mathrm{L}$ penggunaan teknik anestesi neuraxial direkomendasikan pada wanita hamil dengan ITP yang asimptomatik. Beberapa penelitian merekomen-dasikan monitoring menggunakan thromboelastography (TEG) dan rotational thromboelastometry (ROTEM) sebelum melakukan anestesi neuraxial untuk mendeteksi adanya komplikasi hematoma epidural atau spinal. Beberapa penelitian menunjukkan penggunaan teknik anestesi neuraxial pada wanita hamil dengan ITP dengan angka trombosit $<75.000 / \mu \mathrm{L}$ dan berhasil tanpa ada komplikasi post operatif. Anestesia regional merupakan kontraindikasi absolut pada pasien dengan angka trombosit sangat rendah dan memiliki severe coagulopathy. ${ }^{2,12}$

Teknik anestesi neuraxial pada wanita hamil dengan ITP memiliki risiko komplikasi berupa hematoma spinal-epidural. Hematoma spinalepidural merupakan kumpulan darah pada neuraxis spinal yang dapat mengkompresi medulla spinalis dan saraf yang dapat

Tabel 8. Treatment ITP Sesuai Usia Kehamilan

\begin{tabular}{|c|c|}
\hline Trimester pertama & $\begin{array}{ll}\text { - } & \text { Kortikosteroid, } \\
\text { - } & \text { IVIG, } \\
\text { Tranfusi TC jika } \\
\text { bleeding, } \\
\text { - Imunosupresan agent, }\end{array}$ \\
\hline Trimester Kedua & $\begin{array}{l}\text { - } \quad \text { Kortikosteroid, } \\
\text { - } \quad \text { IVIG, } \\
\text { B cell depleting therapy, } \\
\text { Imunosupresan agent, } \\
\text { - } \quad \text { IV anti D, } \\
\text { - } \quad \text { splenectomy, } \\
\text { Tranfusi TC jika bleeding }\end{array}$ \\
\hline Trimester Ketiga & $\begin{array}{l}\text { - Kortikosteroid, } \\
\text { - IVIG, } \\
\text { - IV anti D, } \\
\text { Tranfusi TC jika bleeding }\end{array}$ \\
\hline
\end{tabular}

mengakibatkan disfungsi neurologis. Estimasi insidensi terjadinya komplikasi hematoma spinal-epidural pada populasi wanita hamil yaitu 1/168.000 setelah pemberian epidural, sedangkan tidak terdapat data pada pasien setelah pemberian spinal. Sebuah penelitian menunjukkan risiko terjadinya hematoma epidural sebesar $11 \%$ pada kondisi trombosit $<50.000 / \mathrm{mcL}, 3 \%$ pada trombosit $50.000 / \mathrm{mcL}-69.000 / \mathrm{mcL}$, dan $0,2 \%$ pada trombosit $70.000 / \mathrm{mcL}-100.000 /$ mcL. Beberapa faktor yang mempengaruhi terbentuknya hematoma yaitu terdapat abnormalitas pada medulla spinalis, penempatan jarum injeksi yang sulit, koagulopati, ukuran jarum yang besar, dan penempatan kateter. ${ }^{1}$

Untuk mengurangi risiko terjadinya komplikasi neurologis akibat anestesia regional, beberapa peneliti merekomendasikan penggunaan anestesi general. Pada pasien dengan severe trombositopenia dibutuhkan transfusi trombosit sebelum dilakukan tindakan operasi. Obat-obatan antifibrinolitik seperti asam aminokaproat atau asam tranexamat dapat membantu menstabilkan bekuan darah clot yang sudah terbentuk dan dapat mengurangi jumlah perdarahan selama operasi dan transfusi. Obat-obatan antiinflamasi non-steroid (NSAID) dan penggunaan injeksi intramuscular harus dihindari. Pemberian steroid dan imunoglbulin intravena dilanjutkan sampai dengan operasi berlangsung. Maneuver airway dilakukan dengan teknik atraumatik dan hindari penggunaan intubasi nasal. Monitoring untuk komplikasi perdarahan dilakukan sampai dengan perawatan post operatif. ${ }^{3}$

\section{Simpulan}

Idiopathic thrombocytopenic purpura (ITP) adalah kelainan autoimun dimana terjadi penghancuran sel trombosit oleh sistem retikuloendotelial yang menyebabkan penurunan jumlah trombosit. Terapi ITP lini pertama yaitu pemberian steroid dan immunoglobulin intravena. Pada wanita hamil dengan ITP memiliki risiko perdarahan, untuk itu pemberian transfusi trombosit dan pemantauan perdarahan penting dilakukan pada saat melahirkan. Pada kasus dilaporkan tiga wanita hamil yang akan 
menjalani prosedur seksio sesarea dengan menggunakan teknik anestesi general. Meskipun guidelines of British Committee for Standards in Haematology merekomendasikan penggunaan anestesi neuraxial, namun anestesi general lebih dianjurkan untuk mencegah komplikasi disfungsi neurologis pada medulla spinalis. Penggunaan anestesi general harus dilakukan secara hati-hati. Maneuver airway dilakukan secara atraumatik dan penggunaan intubasi nasal sebaiknya dihindari. Perawatan post operatif pasien sebaiknya dirawat di intensive care unit (ICU) untuk memonitor trombosit dan komplikasi yang dapat terjadi.

\section{Daftar Pustaka}

1. Davis LA. Anesthetic considerations for the parturient with immune thrombocytopenic purpura. Nursing Capstones. 2018: 169. Accessed December 2, 2020.

2. Ozbilgin S, Balkan BK, \& Sasmaz B. Anesthesia for caesarean section of pregnant women with idiopathic thrombocytopenic purpura. Turk J Anaesth Reanim. 2013; 41: 175-7.

3. Suparna M, Rudra AP, \& Jyotsna G. Anesthesia management of patient with idiopathic thrombocytopenic purpura - a case series. J Anesth Ther. 2018; (1): 105. Accessed December 2, 2020.

4. Jamal S, Goel N, Mehta A, \& Ahuja M. Recurrent severe gestational thrombocytopenia in pregnancy: a case report. Int J Adv Med. 2017; 4(6): 1702 1705.

5. Sumathy V, Devi C, \& Padmanaban S. Prospective study of thrombocytopenia in pregnancy. International Journal of Clinical Obstetric and Gynaecology. 2019; 3(1): 17 21.

6. Amorim JG, Abecasis MR, \& Rodrigues FM. Refractory severe thrombocytopenia during pregnancy: how to manage. Rev Bras Ginecol Obstet. 2018; 40: $803-807$.
7. Yan M, Malinowski AK, \& Shehata N. Thrombocytopenic Syndromes in Pregnancy. Obstetric Medicine. 2016; 9(1): 15-20.

8. Becocci A, Civitillo CF, Laurent M, Boehlen F, Luca R, \& Fluss J. Intracranial hemorrhage and autoimmune thrombocytopenia in a neonate: a rare unpredictable event. Child Neurology Open. 2018; 5: 1-5.

9. Nazeer RM, \& Patil MA. Thrombocytopenia in pregnancy and its correlation with maternal and fetal outcome. Journal of Critical Review. 2020; 7(12).

10. Izak, M, Bussel J. Management of thrombocytopenia F1000Prime Reports. $2014 ; 6$.

11. Fadiloglu E, Unal C, Tanacan A, Portakal O, Beksac MS. 5 years' experience of a tertiary center with thrombocytopenic pregnancies: Gestational thrombocytopenia, idiopathic thrombocytopenic purpura and hypertensive disorders of pregnancy. Geburtshilfe Frauenheilkd. 2020;80(1):76-83.

12. Straube LE, de Ridder GG, Huber CA, Blacker SN. Spinal anesthetic in a patient with a platelet count of 7000 $\times 109 / \mathrm{L}$ and undiagnosed thrombotic thrombocytopenic Purpura: A case report: A case report. A A Pract. 2020;14(6):e01184

13. Neunert CE, Cooper N. Evidence-based management of immune thrombocytopenia: ASH guideline update. Hematology Am Soc Hematol Educ Program 2018;568-75.

14. RACP: The Haematology Society of Australia and New Zealand top 5 Evolve lowvalue practices and interventions. Sydney, NSW: RACP, 2015 September [cited 2019 Jan 30]; Available from: https://evolve.edu. $\mathrm{au} /$ published-lists/hsanz/

15. Rajasekhar A, Gernsheimer T, Stasi R, James AH. 2013 Clinical practice guide on thrombocytopenia in pregnancy. Washington, 
DC: American Society of Hematology;2013 cited 2019 Jan 31. Available from. http://www.hematology.org/Clinicians/ GuidelinesQuality/Quick-Reference.aspx.

16. Eslick R, McLintock C. Managing ITP and thrombocytopenia in pregnancy. Platelets. 2020;31(3):300-6.

17. CareA,PavordS,KnightM,AlfirevicZ. Severe primary autoimmune thrombocytopenia in pregnancy: a national cohort study. $\mathrm{Br} \mathrm{J}$ Obstet Gynaecol 2018;125:604-612.

18. Gilmore KS, McLintock C. Maternal and fetal outcomes of primary immune thrombocytopenia during pregnancy: A retrospective study. Obstet Med 2018;11:1216. 